\title{
Avian pox in seabirds on Marion Island, southern Indian Ocean
}

S Schoombie ${ }^{1 *}$, J Schoombie ${ }^{1}$, A Oosthuizen ${ }^{2}$, E Suleman ${ }^{2}$, MGW Jones ${ }^{1}$, L Pretorius ${ }^{3}$, BJ Dilley ${ }^{1}$ and PG Ryan ${ }^{1}$

${ }^{1}$ FitzPatrick Institute of African Ornithology, DST-NRF Centre of Excellence, University of Cape Town, Rondebosch 7701, South Africa

${ }^{2}$ Infectious and Parasitic Disease Program, Research and Scientific Services, National Zoological Gardens of South Africa, P O Box 754, Pretoria 0001, South Africa

${ }^{3}$ Mammal Research Institute, Department of Zoology and Entomology, University of Pretoria, Pretoria 0002, South Africa

*Corresponding author, e-mail: schoombie@gmail.com 


\section{Abstract}

Albatrosses are among the most threatened groups of seabirds with the main land-based threats being alien invasive species, human disturbance and habitat degradation. Disease outbreaks in Antarctic and sub-Antarctic seabird populations are uncommon, but in the past few decades there has been an increase in reported cases. The sub-Antarctic Prince Edward Islands $\left(46^{\circ} \mathrm{S}, 37^{\circ} \mathrm{E}\right)$ in the southwestern Indian Ocean provide breeding grounds for many seabird species, including $44 \%$ of all wandering albatrosses (Diomedea exulans L.). In 2015, five wandering albatrosses and two penguins (Eudyptes chrysocome Forster, Aptenodytes patagonicus Miller) with pox-like lesions were observed on Marion Island, the larger of the two Prince Edward Islands. Despite intensive study of the wandering albatross population since the 1980s, the only previous record of such lesions was one case in 2006 and another in 2009 on white-chinned petrels (Procellaria aequinoctialis L.). Molecular and phylogenetic analysis of tissue samples from two albatross chicks confirmed the presence of avian pox virus (Avipoxvirus). This highlights the need for research into the diseases present on sub-Antarctic islands, for strict controls to limit the risk of accidental introduction of diseases through human activities, and the need for effective conservation measures in the event of an outbreak.

Keywords: disease, Procellariiformes, Sphenisciformes, sub-Antarctic, Avipoxvirus 
Schoombie et al. (2017) Avian pox in Marion Island seabirds

\section{Introduction}

Globally, seabirds are the most threatened group of birds, mainly due to the impacts of fisheries at sea (through direct mortality or competition for resources) and/or on-land threats at their breeding colonies, such as alien invasive species, habitat degradation and human disturbance (Phillips et al. 2016). Among seabirds, albatrosses and petrels (Procellariiformes) and penguins (Sphenisciformes) are the most threatened groups. Most albatrosses and penguins breed on islands in the Southern Ocean where their isolation and the harsh climate shield them from pathogens to some extent (Boersma 2008, Phillips et al. 2016). However, an increase in the number of reported cases of diseases within subAntarctic and Antarctic seabird populations within the last two decades is a cause for concern as warming temperatures and increased human visitation may increase the likelihood of diseases reaching these isolated areas (Weimerskirch 2004, Phillips et al. 2016).

Historically, disease outbreaks in albatrosses and large petrels were mostly reported for species breeding at tropical islands in the North Pacific Ocean (Warner 1968, Sileo et al. 1990, Uhart et al. 2017) and the Falkland Islands, which support a permanent human population and considerable agricultural activities (Munro 2007). However, during the last two decades, several disease outbreaks have been reported within sub-Antarctic and Antarctic seabirds (Weimerskirch 2004, Leotta et al. 2006, Munro 2007, Shearn-Bochsler et al. 2008, Cooper et al. 2009, Grimaldi et al. 2015, Uhart et al. 2017).

Avian pox (genus Avipoxvirus) is a large, double-stranded, enveloped virus with a global distribution (van Riper III et al. 2002). It is easily spread, and is able to infect most bird 
species (Bolte et al. 1999, van Riper III et al. 2002, van Riper III \& Forrester 2007), but is seldom reported from seabirds (VanderWerf \& Young 2016). Avian pox can be spread in a number of ways, including arthropod vectors (Forrester 1991, van Riper III \& Forrester 2007, Kane et al. 2012, Uhart et al. 2017), physical contact with infected tissue (ShearnBochsler et al. 2008, Young \& VanderWerf 2008), ingestion of infected carcasses (Hubálek 2004) or occasionally by aerosol transmission in confined spaces (van Riper III et al. 2002, van Riper III \& Forrester 2007). Symptoms of avian pox most commonly include dry lesions on the unfeathered parts of the infected bird (cutaneous form) and in rare cases wet, necrotic lesions within the respiratory tract (diphtheritic form; van Riper III et al. 2002, van Riper III \& Forrester 2007). Among the Procellariiformes, occurrence of avian pox has been reported most frequently in Laysan albatrosses (Phoebastria immutabilis Rothschild) breeding at islands in the North Pacific (Young \& VanderWerf 2008). However, it also has been reported in black-browed albatrosses (Thalassarche melanophris Temminck) on the Falkland Islands (Munro 2007, Kane et al. 2012), shy albatrosses (T. cauta Gould) on Albatross Island, Tasmania (Woods 2004 cited by Uhart et al. 2017) as well as a single case in black petrels (Procellaria parkinsoni Gray) on Great Barrier Island, New Zealand (Bell et al. 2007). Avian pox also has been reported in wild populations of African (Spheniscus demersus L.; Stannard et al. 1998), Magellanic (S. magellanicus Forster; Kane et al. 2012) and gentoo penguins (Pygoscelis papua Forster; Munro 2007).

The sub-Antarctic Prince Edward Islands ( $46^{\circ} 55^{\prime}$ S, $37^{\circ} 45^{\prime}$ E), comprised of Marion and Prince Edward islands, form part of South Africa. They are important breeding grounds for many seabirds, including five albatross and four penguin species (Ryan \& Bester 2008). Notably, the Prince Edward Islands support the largest breeding population of wandering 
albatross (Diomedea exulans L.; 44\% of the global population), with some 1800 breeding pairs on Marion Island and 1500 on Prince Edward (Ryan et al. 2009). On Marion Island, three wandering albatross colonies have been monitored continuously since the mid1980s, and there are two island-wide counts annually of incubating adults in January and large chicks in November (Nel et al. 2002). In 2015, three wandering albatross chicks within close proximity to each other in the Sealer's Beach study colony (Fig. 1) were found with pox-like lesions on their bills. Tissue samples were collected from two chicks and submitted to the Infectious and Parasitic Diseases Program of the National Zoological Gardens of South Africa (NZG) to confirm the presence of the avian pox virus. This is the first case of avian pox in wandering albatrosses and on Marion Island that is supported by molecular and phylogenetic data. We also summarize previous apparent incidents of avian pox on seabirds at Marion Island.

\section{Methods}

\section{Field work}

The three wandering albatross chicks with pox-like lesions were monitored and photographed weekly between 16 July (discovery of lesions) and 23 September 2015, after which they were monitored twice a month until they fledged in November-December 2015. At each visit, the three individuals and chicks in neighbouring nests were visually inspected, without handling, to look for spread of the virus. Following advice from an avian veterinarian, samples of the lesions were collected from the bills of the two most heavily 


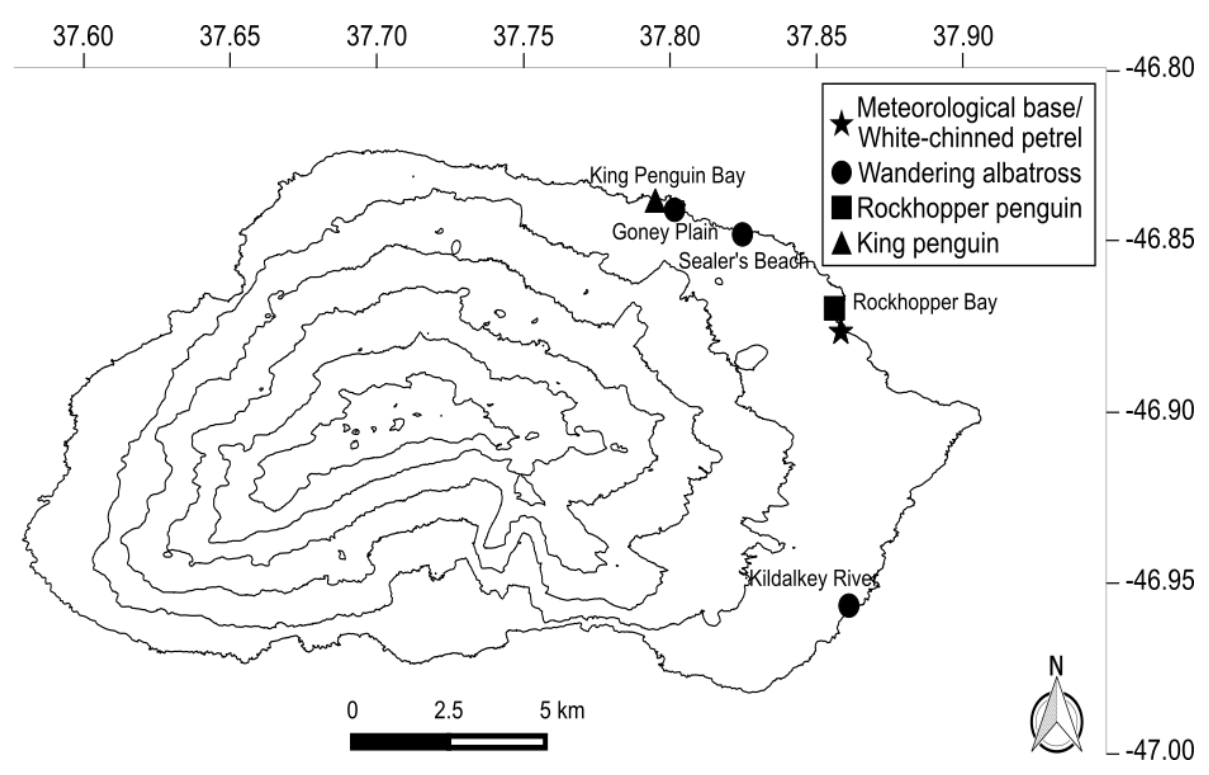

Fig. 1. Locations of possible avian pox infections in four seabird species on Marion Island.

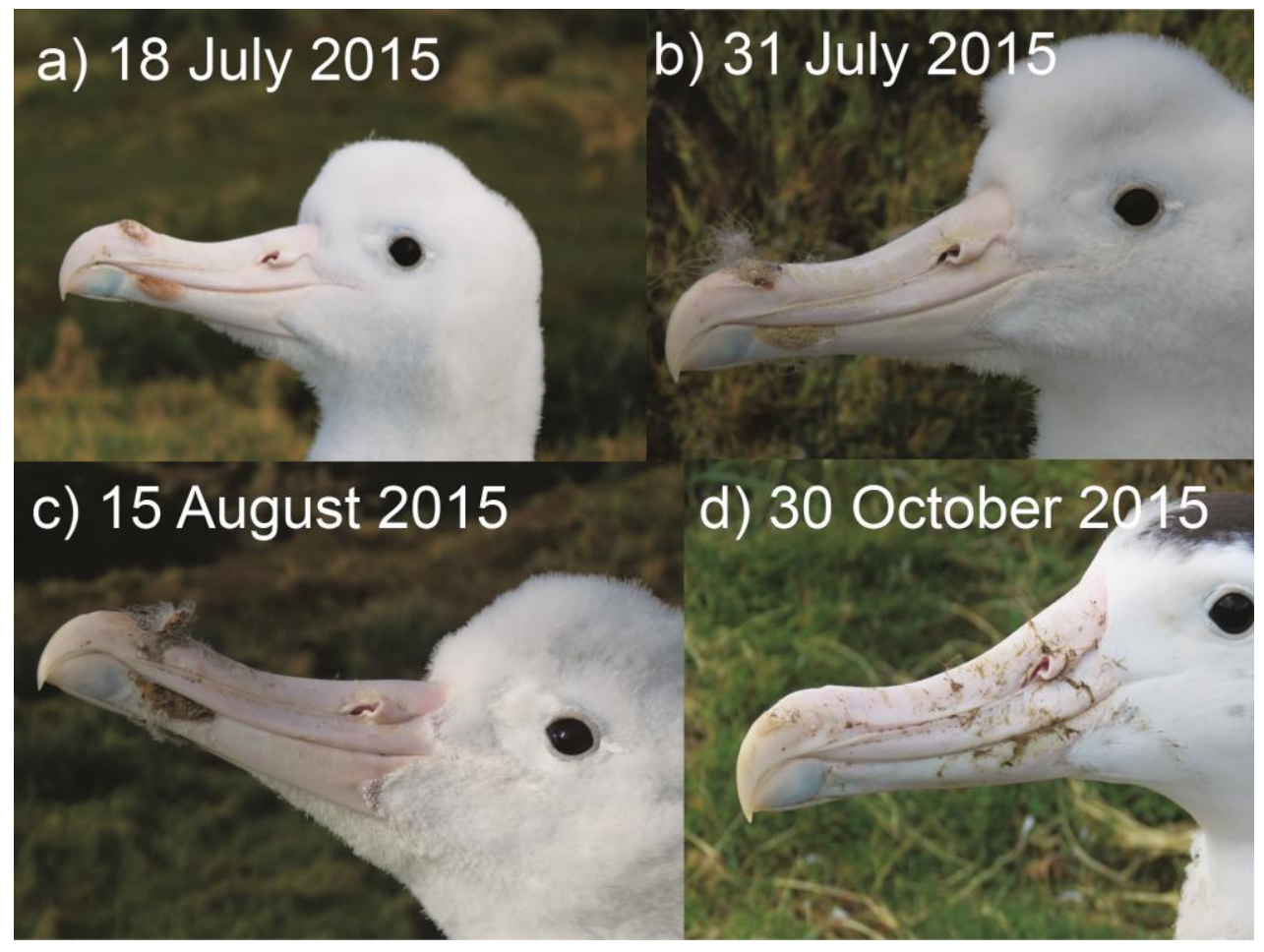

Fig. 2. a-d. Progression of lesions on the bill of a wandering albatross chick on Marion Island infected with avian pox virus (photos by S Schoombie \& J Schoombie). 
affected chicks on 18 July 2015 . Small tissue samples $\left(\sim 5 \mathrm{~mm}^{2}\right)$ were carefully removed with a sterile scalpel, placed in a sterile eppindorf tube, and frozen at $-80^{\circ} \mathrm{C}$ until they could be returned to South Africa for analysis. The sampled areas were disinfected with alcohol swabs and care was taken not to cause excessive bleeding; no further measures were taken as the bleeding stopped shortly after the samples were collected. The samples were frozen within approximately 40 minutes of collection. During sampling, the chicks were inspected for additional lesions inside the mouth and throat as well as the feet and legs (excluding the cloaca). Disposable latex gloves were used when handling infected birds and all clothes coming into contact with infected birds were subsequently disinfected to reduce the risk of spreading the disease. At least 1340 chicks were inspected (without handling) for pox-like lesions during the annual island-wide fledgling count in November 2015. During this count most of the active wandering albatross nests on the island are visited and close-up visual inspection of the chicks is conducted. Previous field workers on Marion Island were asked whether they had observed similar lesions on seabirds in previous years.

\section{Lab work}

DNA was extracted from the two tissue samples $(\sim 25 \mathrm{mg})$ using the MasterPure ${ }^{\mathrm{TM}}$ Complete DNA and RNA Purification Kit (Epicentre; Whitehead Scientific) according to the manufacturer's instructions. Previously published primers were used to differentiate between Low GC content (IMV) and High GC content (RNA polymerase subunit) pox viruses (Li et al. 2010). This was done through selective polymerase chain reaction (PCR) amplification of either an approximately $500 \mathrm{bp}$ region of the pox virus RNA polymerase subunit gene region or approximately 220 bp of intracellular mature virion gene (IMV), 
respectively (Li et al. 2010). Additionally, amplification of three partially overlapping fragments (400bp, 500bp and 1400bp) of the incomplete viral core protein (P4b) gene was done using combinations of previously designed primers. Each sample was amplified separately in a $25 \mu \mathrm{l}$ reaction consisting of $12.5 \mu \mathrm{l} 2 \times$ DreamTaq Green Mastermix (ThermoFisher Scientific), $1 \mu \mathrm{l}$ (10pmol) of each primer, $2 \mu \mathrm{l}$ extracted DNA and $8.5 \mu \mathrm{l}$ nuclease-free, PCR-grade water. Cycling conditions were as follows: $94^{\circ} \mathrm{C}$ initial denaturation for five minutes; followed by 35 cycles of denaturation $\left(94^{\circ} \mathrm{C}\right.$ for $\left.30 \mathrm{sec}\right)$, primer annealing $\left(48^{\circ} \mathrm{C}\right.$ for $\left.50 \mathrm{sec}\right)$ and extension $\left(72^{\circ} \mathrm{C}\right.$ for one minute); a final extension at $72^{\circ} \mathrm{C}$ for 10 minutes with an infinite hold at $4^{\circ} \mathrm{C}$ (Li et al. 2010). Agarose gel electrophoresis (2\% agarose in $1 \times$ Tris-Borate EDTA buffer run at $135 \mathrm{~V}$ for 28 minutes) was used to visualize PCR amplification products (data not shown). Positive PCR amplicons were purified enzymatically using Exonuclease I and Shrimp Alkaline Phosphatase (ThermoFisher Scientific). The purified product was sequenced using the BigDye V3.1 chemistry (ThermoFisher Scientific) and analyzed on an ABI 3500 Genetic Analyzer (Applied Biosystems). Sequencing was conducted in a $10 \mu \mathrm{l}$ reaction consisting of $0.7 \mu \mathrm{l}$ BigDye, $2.55 \mu \mathrm{l}$ BigDye sequencing buffer, $1 \mu \mathrm{l}$ (10pmol) primer and $0.75 \mu \mathrm{l}$ nuclease-free, PCR-grade water. This was done in separate reactions for both the forward and reverse primer to ensure the full fragment was sequenced. The generated partial RNA polymerase subunit sequences were aligned using MEGA6 (Tamura et al. 2013) and deposited in GenBank (accession numbers KY496935-KY496936). The National Centre for Biotechnology Information (NCBI) Basic Local Alignment Search Tool (BLAST; Clark et al. 2016) was used to determine if these sequences were homologous to avipoxvirus sequences in the GenBank database. Thereafter, phylogenetic analysis was conducted using 
MEGA6 (Tamura et al. 2013) to determine how closely related the pox virus sequences generated in this study were to other avipoxvirus sequences in GenBank. This was done by first aligning the sequences obtained, then using NCBI BLAST to obtain reference sequences from GenBank for comparison, which included P4b gene sequences.

Phylogenetic analysis of the partial RNA polymerase subunit gene was conducted on a small subsample ( $\mathrm{n}=12)$ of related sequences from GenBank (AF198100, AY318871, AY386263, DQ356948, KJ801920, KJ859677, KP728110, NC001731, NC005336, NC005337) as well as a pox virus sample from a crocodile as an internal positive control (CROC1). These sequences included the Fowlpox virus, which is the type species for the Avipoxvirus genus, as well as the Canarypox virus.

Phylogenetic analysis of the partial P4b gene was also conducted using a subsample of sequences generated by Gyuranecz et al. (2013; $n=49)$, sequences from GenBank ( $n=34)$, as well as three pox virus samples (two flamingo and one feral pigeon) as internal positive controls (Avipox14B, C, and 137) obtained from the NZG (Table S1). All sequences were trimmed to the shortest sequence in the data set and a phylogenetic model test conducted under the Akaike Information Criterion (AIC) in MEGA6. A Neighbor-Joining (NJ) tree was constructed using the Tamura-3 parameter as determined by the model test, using 1000 bootstrap replicates. 


\section{Results}

\section{Observations of pox-like lesions}

All three affected chicks in the Sealers Beach study colony had raised nodular lesions on their upper mandible, with two chicks also having lesions on their lower mandible (Fig. 2). During the first few weeks after the growths were first observed, they increased in size and turned from pink to brown as they formed a hardened scab, which eventually fell off (Fig. 2). No lesions were observed within the mouth, throat or on the legs/feet of the two chicks that were inspected. All three chicks healed completely, with no scars or serious deformations (Fig. 2d). The first chick, with the smallest lesion (confined to the upper mandible), was fully recovered by 26 August 2015 (39 days), while the remaining two chicks with larger lesions recovered by 30 October (104 days) and 19 November 2015 (124 days). All three chicks fledged in December 2015, similar to other chicks within the study colony. The parents of the three chicks were not seen during nest checks.

Two additional cases of pox-like lesions were observed, one on 4 August 2015 next to Kildalkey River (Fig. 1) where a wandering albatross chick had two small growths on the skin above its left eye (Fig. 3a) and one in the Goney Plain study colony (Fig. 1) where an adult bird had lesions on the webbing of its left foot on 4 March 2016 (Fig. 3b). During the island-wide count of fledglings no additional pox-like lesions were observed. 


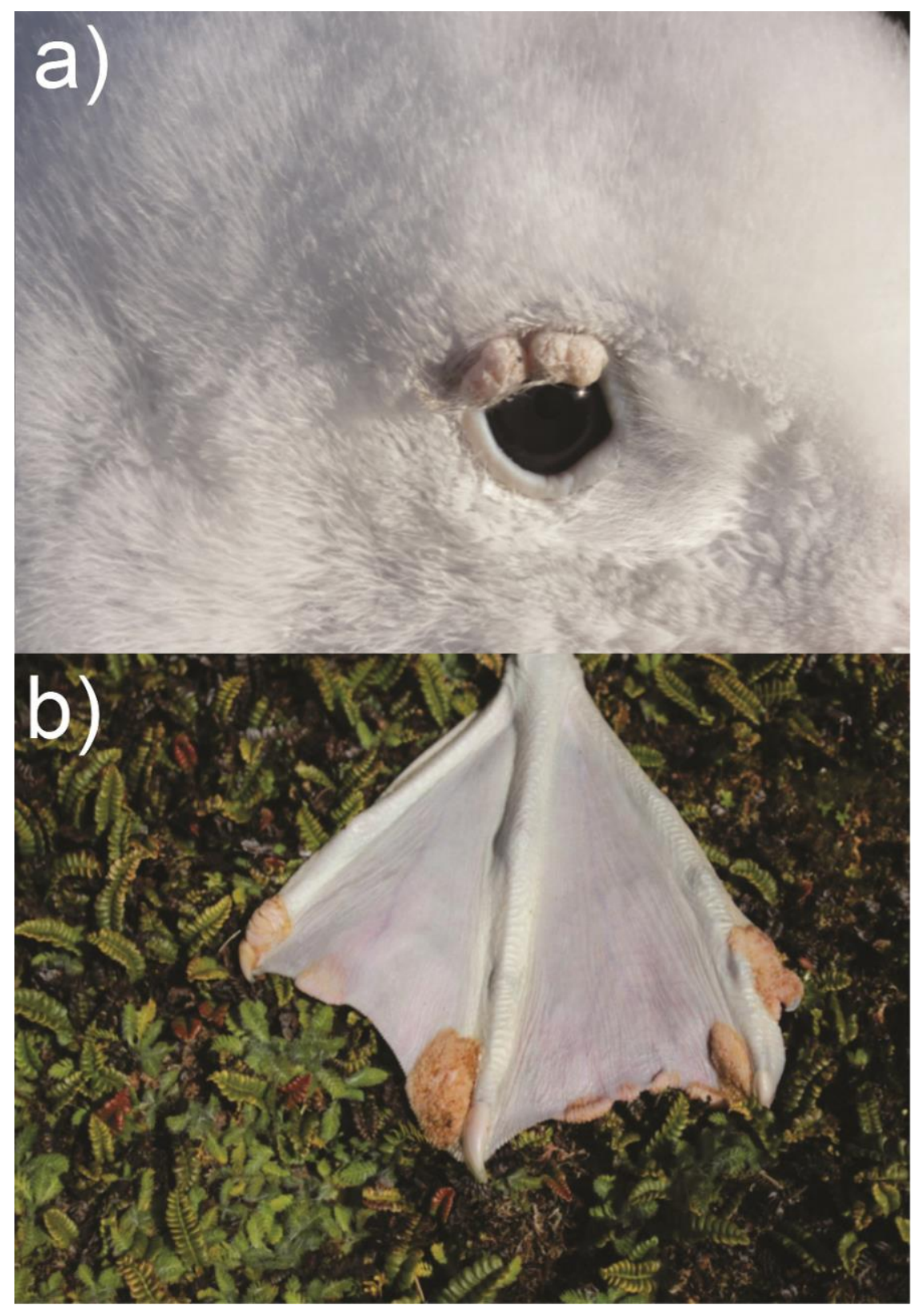

Fig. 3. Avian pox-like lesions on a. a wandering albatross chick on 4 August 2015 and b. an adult bird found on Marion Island on 4 March 2016 (photos by S Schoombie). 
Only three field workers recalled observing pox-like lesions on Marion Island seabirds. Such lesions were observed on a wandering albatross chick, which was photographed in the Goney Plain study colony in 2006 (Fig. 4a). This chick also recovered, and its bill was almost fully healed by the time it fledged (Fig. 4b). Two adult white-chinned petrels (Procellaria aequinoctialis L.) with pox-like lesions on their feet were photographed in 2009 close to the meteorological base (Fig 5). These birds were part of another study stretching over two breeding seasons (2009/10 and 2012/13) and no more lesions were found on $>70$ white-chinned petrels that were handled during this time. Pox-like lesions also were observed in two penguin species in 2015 (Fig. 6): a southern rockhopper penguin (Eudyptes chrysocome Forster) chick was photographed in Rockhopper Bay (Fig. 1) with pox-like lesions on its flipper on 4 March 2015 (Fig. 6a), and a king penguin (Aptenodytes patagonicus Miller) with large pox-like growths on its neck was photographed at King Penguin Bay (Fig. 1) on 15 Jan 2015 (Fig. 6b). The latter bird had purulent growths (most likely caused by secondary infection) and was seen again on 25 January 2015, when the growths covered its eyes. Unfortunately, no samples were collected from any of these birds.

In addition, two fully-grown white-chinned petrels with pox-like growths on their feet were observed among 2638 birds examined after being drowned on long-lines set for tuna off South Africa between 2002 and 2016; one killed in September 2005 and another in May 2008 (Fig. S1). The growths were soggy after immersion for approximately 24 hours followed by freezing for several months, but could be further records of avian pox in a procellariiform from the southwest Indian Ocean. No growths were found on 1158 fully 


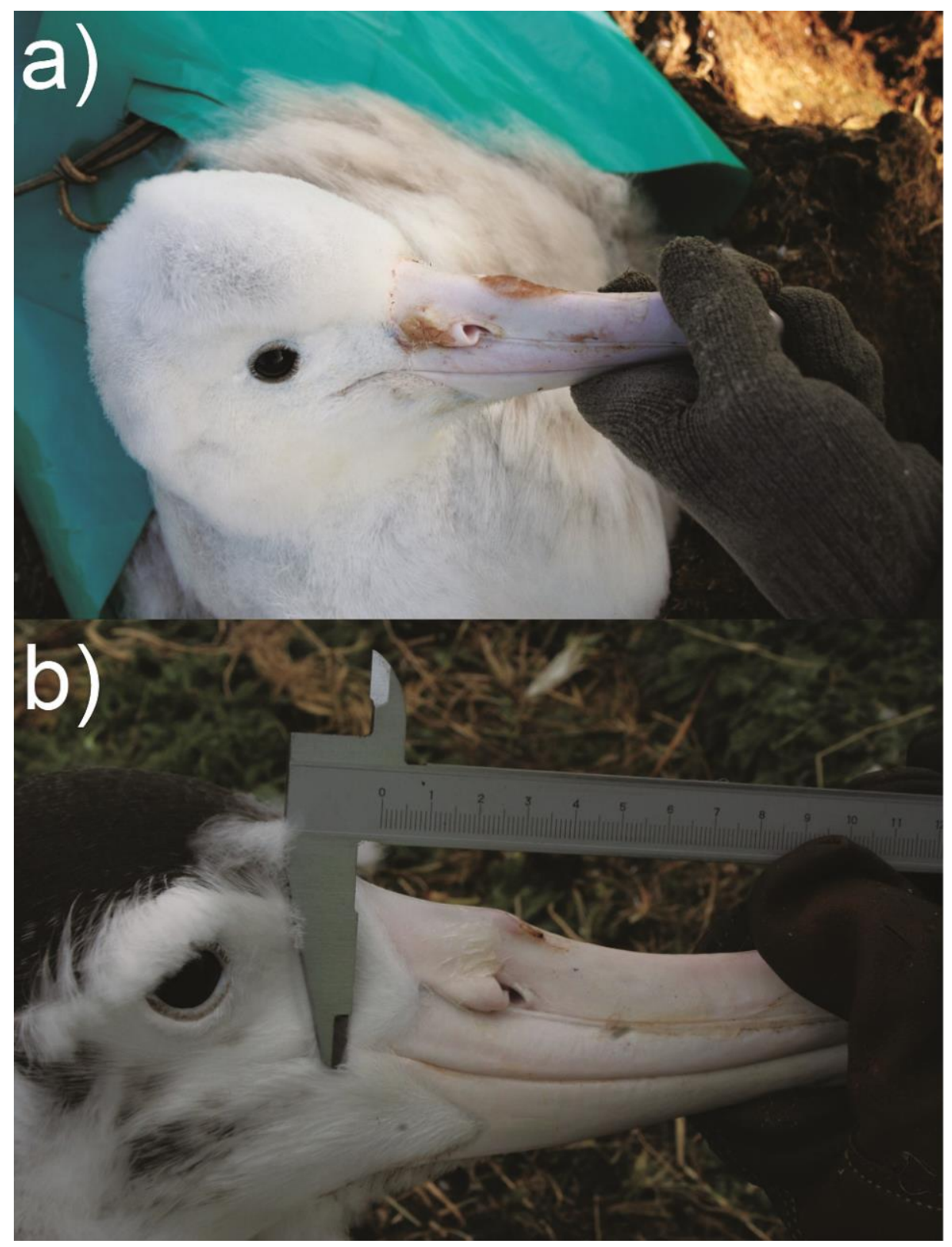

Fig. 4. a. Avian pox-like lesions on a wandering albatross chick on 17 August 2006. b. The chick had mostly lost the lesions by 4 October 2006 (photos by MGW Jones). 
Schoombie et al. (2017) Avian pox in Marion Island seabirds

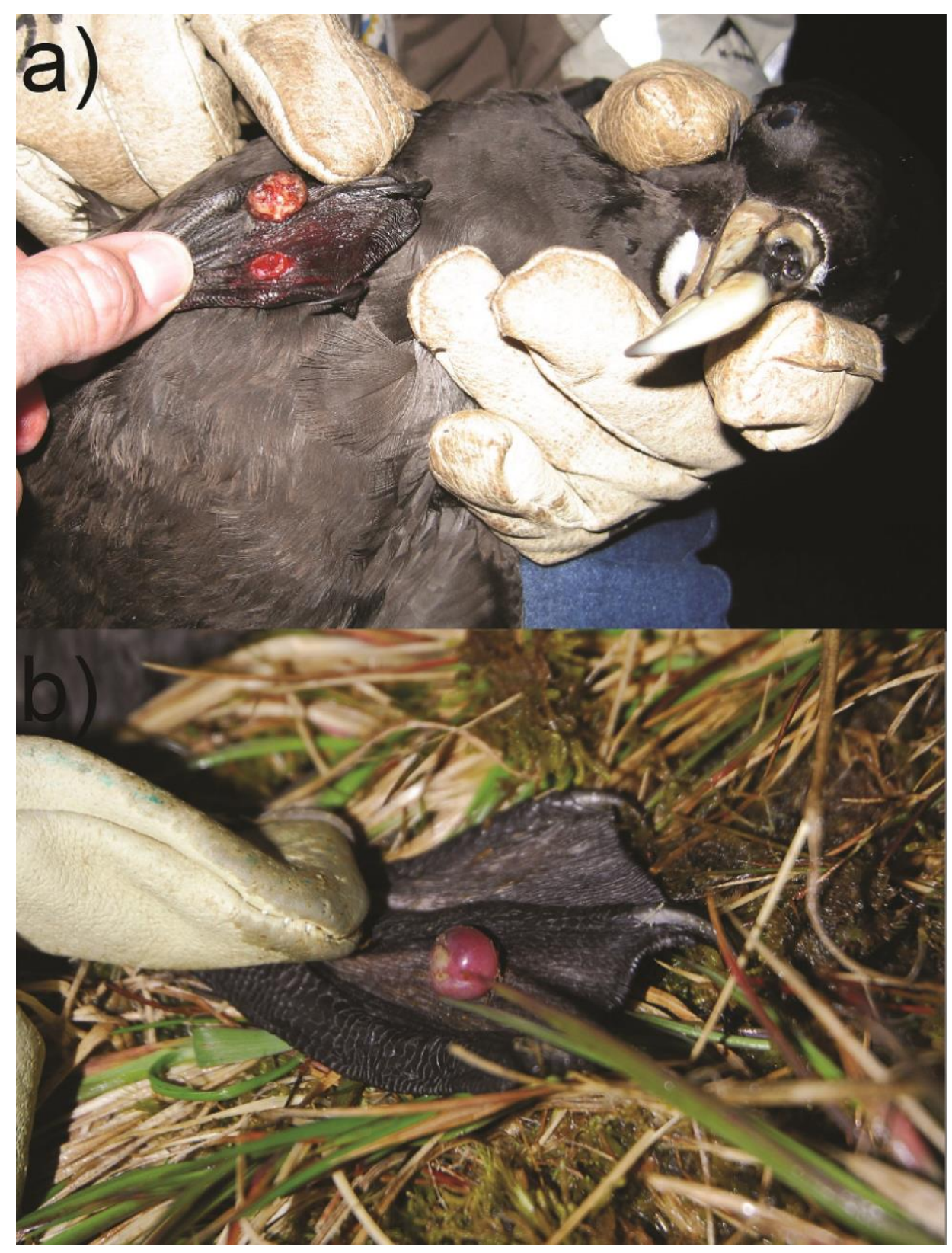

Fig. 5. a-b. Avian pox-like lesions on two adult white-chinned petrels found on Marion Island on 9 November 2009 (photos by BJ Dilley). 


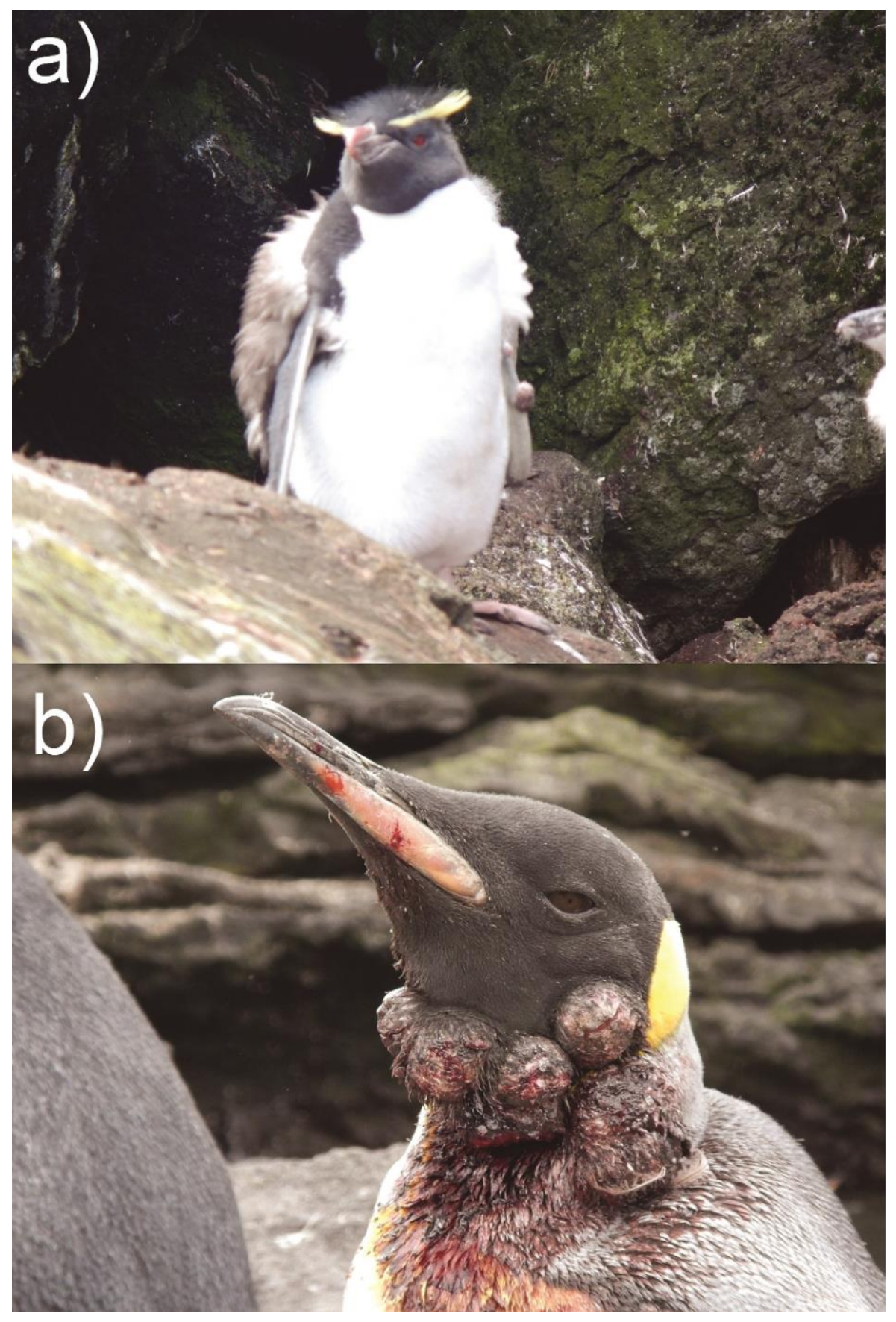

Fig. 6. Pox-like growths on penguins on Marion Island: a. Molting adult southern rockhopper penguin with a growth on its left flipper (4 March 2015); b. Adult king penguin with growths on its neck (15 January 2015; photos L Pretorius). 
Schoombie et al. (2017) Avian pox in Marion Island seabirds

grown albatrosses from eight species or 45 other petrels from five species killed by this fishery (PGR unpubl. data).

\section{Confirmation of Avipoxvirus}

Agarose gel electrophoresis of PCR products from the albatross bill lesions showed that an approximately 500 bp (RNA polymerase subunit gene) and 1400bp (P4b gene) bands were successfully amplified in both samples indicating the presence of a high GC pox virus in the tissue samples analyzed in this study. Sequencing of these bands was successful and sequence alignment (in MEGA6) confirmed that the sequences were identical. BLAST analysis confirmed that these sequences were from a pox virus. The partial RNA polymerase subunit gene sequences were similar (78\% identical; $\left.\mathrm{E}=3 \times 10^{-119}\right)$ to a pox virus sequence (GenBank accession number: KP728110) obtained from a domestic turkey (Meleagris gallopavo L.) from Hungary in 2011 and 75\% identical to other pox virus sequences. The partial P4b gene sequences were similar $(74 \%$ identical; $\mathrm{E}=0.0)$ to a pox virus sequence (GenBank accession number: AY318871) obtained from a canary (Serinus canaria domestica L.) from the USA in 1948 and 73\% identical to other pox virus sequences.

Phylogenetic analysis based on the partial RNA polymerase subunit gene sequences (Fig. 7a), showed that the pox virus from the albatrosses was more distantly related (based on branch lengths) to pox viruses from the USA (AF198100, AY318871), as well as sequences from an African penguin (KJ859677) and a rock pigeon (Columba livia Gmelin; KJ801920) from South Africa. These data are supported by BLAST analyses, which showed 75\% and 76\% identity to the pox viruses from USA and South Africa, respectively. Phylogenetic 
a)
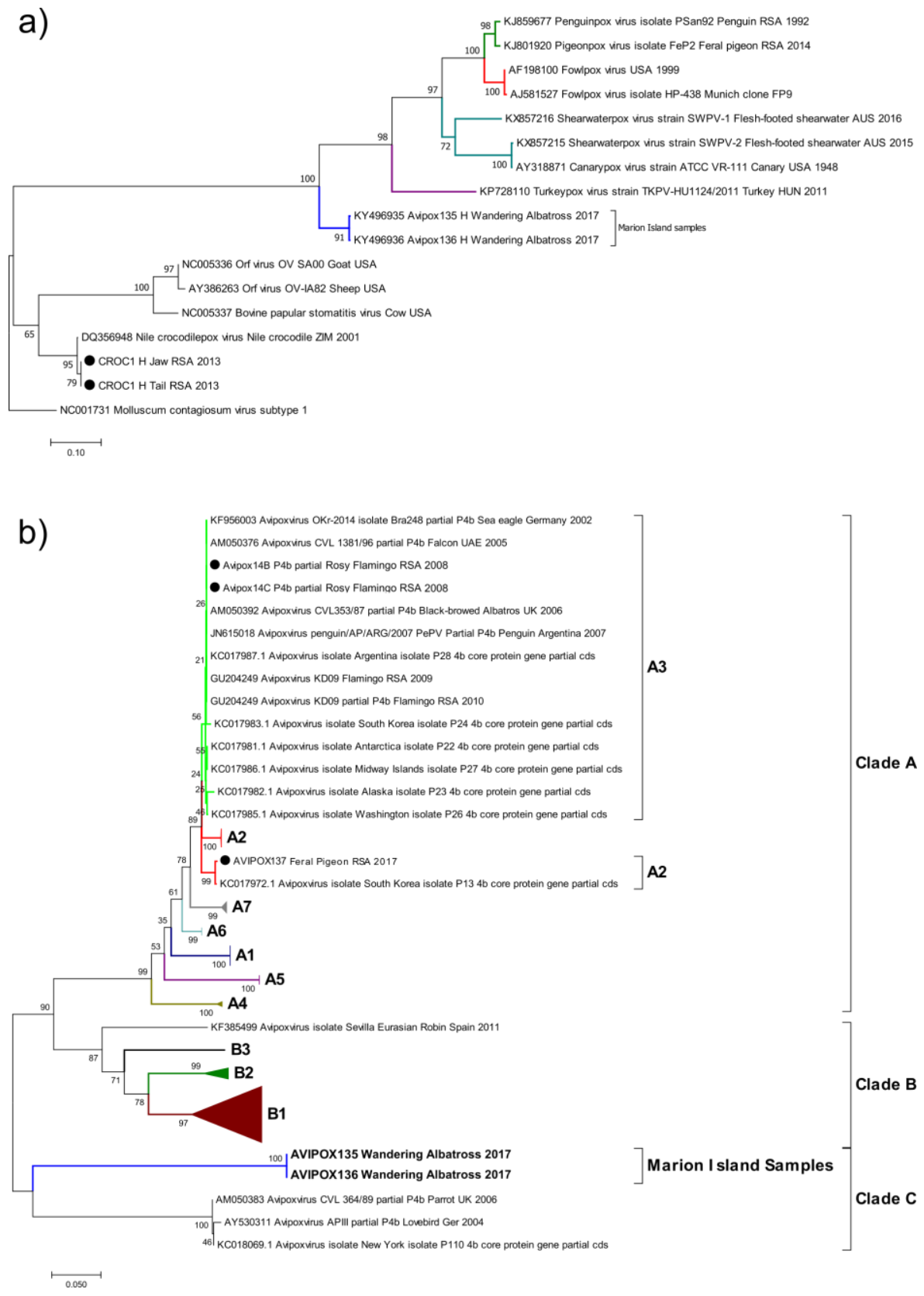

Fig. 7. Neighbor-Joining phylogenetic trees of a. partial RNA polymerase and b. P4b genes, comparing pox virus sequences identified in wandering albatross chicks (Avipox135 and Avipox136) to other pox viruses obtained from GenBank. The tree was rooted with Molluscum contagiosum as an out group, bootstrap analysis $=1000$ replicates. Sub-clades are colour coded and internal controls are indicated with a filled circle. 
analysis based on the partial P4b gene sequences (Fig. 7b) showed that the avipoxvirus were more distantly related (based on branch lengths) to avipoxviruses from: the UK (AM050383), a yellow-crowned amazon (Amazona ochrocephala Gmelin; KC018069) from the US, and a lovebird (Agapornis spp.; AY530311) from Germany.

\section{Discussion}

This is the first confirmed case of avian pox in wandering albatrosses and for birds breeding on Marion Island. Polymerase chain reaction (PCR), sequencing and comparison of sequence data based on the RNA polymerase and P4b genes to other avipoxvirus sequences confirmed the presence of avipoxvirus DNA in both wandering albatross tissue samples analyzed. BLAST analysis of the partial RNA polymerase subunit gene region confirmed that these sequences were similar to a pox virus isolated from a domestic turkey (Bányai et al. 2015) and other pox virus sequences in the NCBI database. Additionally, BLAST analysis of the partial P4b gene indicated similarity to a canary pox virus in the American Type Culture Collection (AY318871; ATCC, VR-111). The results obtained for both genes confirm the presence of a distinct avipoxvirus in the wandering albatross samples obtained from Marion Island. However, the DNA polymerase gene which has been used for phylogenetic analysis of avipoxviruses in a previous study (Gyuranecz et al., 2013) was not analysed. The inclusion of all three gene regions (P4b, RNA polymerase and DNA polymerase) in future phylogenetic analyses may help to better elucidate the phylogeny of avipoxviruses. 
Our results provide strong evidence that an avipoxvirus was responsible for causing the infection and lesions in the wandering albatross chicks. The detected virus however does not appear to be related to any of the A and B clades as determined by Gyuranecz et al. (2013), and appears to be distantly related to the C clade which represents Psittacinepox viruses and included avian pox viruses isolated from a parrot from the UK, a lovebird from Germany, and a Yellow-crowned amazon form the US (Fig 7b). Phylogenetic analysis of the P4b gene sequences by Gyuranecz et al. (2013) used a partial region (426bp) while the entire P4b gene is approximately 1979bp in length which may affect how samples cluster. Sequencing, BLAST and phylogenetic results indicate that this may be a previously undescribed or novel avian pox virus, but further research and characterization (e.g. histopathology, whole genome sequencing, viral culture, electron microscopy) is required to confirm this.

Avian pox virus infections are of concern because this virus is highly contagious, presents with the possibility of recurring outbreaks, and most bird species are probably susceptible to the virus (van Riper III et al. 2002, Young \& VanderWerf 2008, Phillips et al. 2016). The cutaneous form of avian pox observed in this study is the most common form and infected individuals mostly recover if no secondary infection or gross deformation occurs (Bolte $e t$ al. 1999, van Riper III et al. 2002). However, it has been shown that the long-term survival and recruitment rates of Laysan albatrosses are decreased if they were previously infected with avian pox (VanderWerf \& Young 2016).

Recently, avian pox in sub-Antarctic and Antarctic breeding seabirds have been reported for penguins (Spheniscidae; Munro 2007, Kane et al. 2012, Grimaldi et al. 2015), and 
albatrosses and large petrels (Procellariiformes; Shearn-Bochsler et al. 2008, Uhart et al. 2017). Marion Island provides breeding grounds for four albatrosses (Diomedea exulans L., Thalassarche chrysostoma Forster, Phoebetria fusca Hilsenberg and P. palpebrata Forster), both giant petrels (Macronectes giganteus Gmelin and M. halli Mathews) and four penguin species (Aptenodytes patagonicus Miller, Eudyptes chrysolophus Brandt, E. chrysocome Forster and Pygoscelis papua Forster; Ryan \& Bester 2008). Currently, light-mantled albatross (Phoebetria palpebrata Forster; Ryan et al. 2009, Schoombie et al. 2016) and both Eudyptes penguin (Crawford et al. 2009) populations are decreasing on Marion Island and disease outbreaks could place further pressure on these populations. Two previous accounts of disease outbreaks have been reported for Marion Island (Cooper et al. 2009); one in 1993 when 5000-10000 macaroni penguins (Eudyptes chrysolophus Brandt) were killed by an unknown disease and another in 2004 when 2000 macaroni penguins were killed by avian cholera (Pasteurella multocida Lehmann and Neumann).

Although there is only one previous record of possible avian pox in wandering albatrosses on Marion Island, it might have been overlooked in the past. The pox lesions in all affected wandering albatross chicks lasted 1-4 months and signs of the lesions were largely invisible by fledging in mid-November. On Marion Island, only one island-wide count of wandering albatross chicks is performed early in November, just before the chicks fledge (Nel et al. 2002). Thus, if wandering albatross chicks outside of the monitoring colonies contracted the avian pox virus it would most probably go undetected. Likewise most surface-nesting seabirds breeding on Marion Island are only checked annually, mostly from a distance (Nel et al. 2002, Crawford et al. 2009). All of the avian pox (or suspected pox) observations were made close to the meteorological base on the island. This is most likely 
due to the sampling effort being higher in this area as most of the monitoring studies are done close to the base. Pox-like lesions are easily overlooked while counting groups of birds. The observation of pox-like lesions in penguins made in 2015 was done while working on seals; work that included being in close proximity to several penguins species. This highlights the need for close inspection of seabirds on Marion Island to determine the extent to which avian pox might be present.

Wandering albatrosses from the southwest Indian Ocean colonies range widely at sea (Weimerskirch et al. 2014, FitzPatrick Institute of African Ornithology unpubl. data) with the potential to come into contact with a variety of diseases while courting or competing for large food items. Immature ticks carried by seabirds can be transported between continents, spreading tick-borne diseases, including avian pox (Hubálek 2004). Avian pox has a global distribution (van Riper III et al. 2002) and different strains may be carried to remote islands such as Marion Island by far ranging seabirds. On Marion Island, avian pox is perhaps most likely to be spread by arthropods and especially ixodid ticks (Hubálek 2004) which are found on many albatrosses, including wandering albatrosses (Uhart et al. 2017). Additionally, avian pox might be spread by scavengers such as giant petrels or brown skuas (Stercorarius antarcticus Lesson). Giant petrels have been reported killing chicks of wandering and sooty albatrosses (Dilley 2013, Dilley et al. 2013) and could potentially spread avian pox between species as they are frequently found in penguin colonies (Ryan \& Bester 2008). Inter-species transmission of avian pox is largely dependent on contact rate, which is low for birds breeding on Marion Island. However, brown skuas often harass white-chinned petrels without necessarily killing them (pers. obs.), which could lead to the transmission of avian pox. Likewise, failed predation 
attempts of giant petrels could have the same effect. Physical contact is common among penguins, especially for large chicks that form dense crèches to reduce the risk of predation. As a result, avian pox (and other diseases) could easily spread within penguin colonies. Apart from natural processes, avian pox could also be spread by researchers when contaminated clothing or equipment are not properly disinfected or when arthropods are transported between sites on clothes of researchers (Uhart et al. 2017).

Avian pox is easily overlooked if detection rests on visual observation, because this is difficult to perform on a regular basis as many seabirds breed in hard to reach places on sub-Antarctic islands (e.g. cliff nesting albatrosses; burrow-nesting petrels). Additionally, birds infected with avian pox might be asymptomatic as avian pox has a relatively long latent phase (van Riper III \& Forrester 2007), making it impossible to detect infection from visual cues. Screening blood samples for antibodies would be a more effective way to determine if birds have been exposed to an avian pox virus (Uhart et al. 2017). On Marion Island, the occurrence of avian pox virus might be widespread as individuals from four species and five distinct locations were found with pox-like lesions. Molecular and phylogenetic analysis of infected tissue from only two birds (from one site) supported Avipoxvirus as the causal agent, but the characteristic cutaneous lesions of avian pox provide a reasonably reliable diagnosis (Bolte 1999). Nonetheless, even if the unconfirmed cases of pox presented here were caused by another pathogen, it highlights the recent wide spread occurrence of disease across multiple species on Marion Island.

The detected avipoxvirus (this study) was similar to a virus detected in turkeys, suggesting a link with poultry. Although no fresh produce or boned poultry products are allowed at 
the Prince Edward Islands (de Villiers et al. 2005), live chickens (Gallus gallus L.) were sent to Marion Island between 1950 and 1970 (Watkins \& Cooper 1986). The chickens were kept in an outdoor cage that was removed in 1972 (Watkins \& Cooper 1986), but the last remnants of the structure were only removed in the 2000s (John Cooper pers. comm.). These birds could potentially have been a source of avian pox on Marion Island. However, the similarity may simply reflect the paucity of isolates from free-ranging wildlife rather than a direct link with poultry.

Disease outbreaks can be devastating and even cause extinction of certain species over time (Descamps et al. 2012). Although the threat that avian pox poses to seabird populations are not as severe as other diseases (i.e. avian cholera; Descamps et al. 2012), it is possible that the occurrence of avian pox is under-reported. Most of the published literature on avian pox in albatrosses relates to Laysan albatrosses in the North Pacific (Warner 1968, Sileo et al. 1990, Young \& VanderWerf 2008), but there are reports of avian pox in shy albatrosses (Woods 2004, cited by Uhart et al. 2017) and black-browed albatrosses as early as the 1960s (Munro 2007). Our records highlight the need for further study regarding pathogens present in seabirds breeding on Marion Island (cf. Abad et al. 2013). A baseline of pathogens present in a population is necessary to effectively manage potential outbreaks in the future. Diseases might be dormant within a population until a suitable vector is presented, as was the case for Hawaiian seabirds in the early 1800 s when the introduction of mosquitos caused devastating outbreaks of malaria (Warner 1968). Temperature and humidity are linked to the survival of some arthropod species which act as vectors for avian pox virus (Kane et al. 2012) and recent climatic changes on Marion Island (le Roux \& McGeoch 2008) might cause an increase in the survival potential of 
disease vectors on Marion Island. Currently avian disease is not a major concern on Marion Island, but this might change in future. Other on-land threats, such as invasive species (Dilley et al. 2016) or increased temperatures (le Roux \& McGeoch 2008) might reduce the fitness of seabirds, increasing their susceptibility to disease (Young \& VanderWerf 2008, Zylberberg et al. 2012).

The Prince Edward Islands are one of four sub-Antarctic island groups where tourism is not allowed (de Villiers et al. 2005). Recent increases in tourism to Antarctica may have caused an increase in diseases introduced to these remote areas (Grimaldi et al. 2011). The restriction of tourism on the Prince Edward Islands should be continued to reduce the risk of accidental introduction/spread of pathogens. To minimize the risk of accidentally introducing diseases to sub-Antarctic islands, strict and effective quarantine measures need to be in place (de Villiers et al. 2005). The Prince Edward Islands are recognized as a Specially Protected Area, the highest level of protection for natural areas under South African law, and strict quarantine measures currently are in place to limit the introduction of alien species (de Villiers et al. 2005). However, revision of biosecurity protocols on Marion Island is necessary to reduce the risk of disease outbreak or spread of diseases by researchers. Untreated sewage and macerated food waste is currently piped into the sea (de Villiers et al. 2005); this practice should be revised. Clear guidelines should be in place to ensure that researchers use proper techniques and equipment (i.e. meticulous cleaning of field equipment, use of disposable latex gloves) when handling diseased animals. Even experienced field workers may not be familiar with the correct protocols when coming across avian diseases. Specific procedures and conservation measures in the event of a 
disease outbreak is also lacking for the Prince Edward Islands and should be considered for future study.

\section{Acknowledgements}

The authors thank Benoit Morkel, Pierre Joubert and Tegan Carpenter-Kling for assistance in the field. Janelle Ward provided valuable advice on field identification and sampling techniques. Emily Lane provided valuable comments during manuscript preparation. Helene Brettschneider kindly provided primers used for phylogenetic anaylsis. Logistical and financial support was provided by the South African Department of Environmental Affairs, through the South African National Antarctic Programme (SANAP), the National Research Foundation and the University of Cape Town. Eric VanderWerf and another anonymous reviewer provided useful comments on a previous draft of this manuscript.

\section{Supplemental material}

A supplemental table with a list of avipoxvirus sequences analysed and a supplemental figure of pox-like lesions in white-chinned petrels are included.

\section{Author contributions}

SS, JS, MGWJ, LP, BJD and PGR conducted the fieldwork. AO and ES conducted the genetic analysis. SS wrote the first draft of the manuscript. PGR and ES advised on manuscript preparation. PGR supervised the research. 
Schoombie et al. (2017) Avian pox in Marion Island seabirds

\section{References}

Abad, F.X., Busquets, N., SAnCheZ, A., Ryan, P.G., Majó, N. \& GonZAlEz-Solis, J. 2013. Serological and virological surveys of the influenza A viruses in Antarctic and sub-Antarctic penguins. Antarctic Science, 25, 339-344.

Bányai, K., Palya, V., DÉnes, B., Glávits, R., Ivanics, E., Horváth, B., Farkas, S.L., Marton, S., BÁlint, A., GyuraneCZ, M., ERdÉLYI, K. \& DÁN, A. 2015. Unique genomic organization of a novel Avipoxvirus detected in turkey (Meleagris gallopavo). Infection, Genetics and Evolution, 35, 221-229.

BELL, E.A., Sim, J.L., AND SCOFIELD, R.P. 2007. Demographic parameters of the black petrels (Procellaria parkinsoni). DOC Research and Development Series, 273. Department of Conservation. Wellington.

BoERSMA, P.D. 2008. Penguins as marine sentinels. BioScience, 58, 597-607.

Bolte, A.L., Meurer, J. \& KaletA, E.F. 1999. Avian host spectrum of avipoxviruses. Avian Pathology, 28,415-432.

Clark, K., Karsch-Mizrachi, I., Lipman, D.J., Ostell, J. \& Sayers, E.W. 2016. GenBank. Nucleic Acids Research, 44, D67-D72.

Cooper, J., Crawford, R.J.M., De Villiers, M.S., Dyer, B.M., Hofmeyr, G.J.G. \& Jonker, A. 2009.

Disease outbreaks among penguins at sub-Antarctic Marion Island: a conservation concern. Marine Ornithology, 37, 193-196. 
Crawford, R.J.M., Whittington, P.A., Upfold, L., Ryan, P.G., Petersen, S.L., Dyer, B.M. \& Cooper, J. 2009. Recent trends in numbers of four species of penguins at the Prince Edward Islands. African Journal of Marine Science, 31, 419-426.

De Villiers, M.S., Cooper, J., Carmichael, N., Glass, J.P., Liddle, G.M., McIvor, E., Micol, T. \& RoBERTS, A. 2005. Conservation management at Southern Ocean islands: towards the development of best-practice guidelines. Polarforschung, 75, 113-131.

DesCAMPS, S., JenouvRIER, S., GiLCHRIST, H.G. \& ForBes, M.R. 2012. Avian cholera, a threat to the viability of an Arctic seabird colony? PLOS ONE, 7, e29659.

DilLEY, B.J. 2013. Living on the edge: Sooty Albatross chick killed by a Northern Giant Petrel. Ornithological Observations, 4, 138-142.

Dilley, B.J., Davies, D., Connan, M., Cooper, J., De Villiers, M.S., Swart, L., Vandenabeele, S., ROPERT-COUDERT, Y. \& RYAN, P.G. 2013. Giant petrels as predators of albatross chicks. Polar Biology, 36, 761-766.

Dilley, B.J., Schoоmbie, S., Schoombie, J. \& RYAn, P.G. 2016. 'Scalping' of albatross fledglings by introduced mice spreads rapidly at Marion Island. Antarctic Science, 28, 73-80.

FORRESTER, D.J. 1991. The ecology and epizootiology of avian pox and malaria in wild turkeys. Bulletin of the Society for Vector Ecology, 16, 127-148.

GRIMALDI, W.W., JABOUR, J. \& WoEHLER, E.J. 2011. Considerations for minimising the spread of infectious disease in Antarctic seabirds and seals. Polar Record, 47, 56-66. 
Grimaldi, W.W., SEddon, P.J., Lyver, P.O.B., NAKAGAWA, S. \& TomPKins, D.M. 2015. Infectious diseases of Antarctic penguins: current status and future threats. Polar Biology, 38, 591606.

Gyuranecz, M., Foster, J.T., DÁn, A., IP, H.S., Egstad, K.F., PARKER, P.G., Higashiguchi, J.M., Skinner, M.A., HöFle, U., Kreizinger, Z., DorRestein, G.M., Solt, S., Sós, E., Kim Y.J., UhART, M., Pereda, A., GonZález-Hein, G., HidAlgo, H., BlanCo, J. \& ErdélYI, K. 2013. Worldwide phylogenetic relationship of avian poxviruses. Journal of Virology, 87, 4938-4951.

HUBÁLEK, Z. 2004. An annotated checklist of pathogenic microorganisms associated with migratory birds. Journal of Wildlife Diseases, 40, 639-659.

Kane, O.J., Uhart, M.M., Rago, V., Pereda, A.J., Smith, J.R., Van Buren, A., Clark, J.A. \& Boersma, P. DEE. 2012. Avian pox in Magellanic Penguins (Spheniscus magellanicus) Journal of Wildlife Diseases, 48, 790-794.

LE RouX, P.C. \& MCGEOCH, M.A. 2008. Changes in climate extremes, variability and signature on sub-Antarctic Marion Island. Climatic Change, 86, 309-329.

Leotta, G.A., Chinen, I., Vigo, G.B., Pecoraro, M. \& Rivas, M. 2006. Outbreaks of avian cholera in Hope Bay, Antarctica. Journal of Wildlife Diseases, 42, 259-270

LI, Y., Meyer, H., Zhao, H. \& DAmon, I.K. 2010. GC Content-Based Pan-Pox Universal PCR Assay for Poxvirus Detection. Journal of Clinical Microbiology, 48, 268-276.

MunRo, G. 2007. Outbreak of avian pox virus in Gentoo Penguins in the Falklands, February 2006. Falklands Conservation, Falkland Islands. 
Schoombie et al. (2017) Avian pox in Marion Island seabirds

NeL, D.C., Ryan, P.G., CRAWFoRd, R.J.M., COOPER, J. \& HuYSER, O.A.W. 2002. Population trends of albatrosses and petrels at sub-Antarctic Marion Island. Polar Biology, 25, 81-89.

Phillips, R.A., Gales, R., BaKer, G.B., Double, M.C., Favero, M., Quintana, F., Tasker, M.L., WEIMERSKIRCH, H., UHART, M. \& WOLFAARDT, A. 2016. The conservation status and priorities for albatrosses and large petrels. Biological Conservation, 201, 169-183.

RyAN, P.G. \& Bester, M.N. 2008. Pelagic predators. In Chown, S.L. \& Froneman, P.W., eds. The Prince Edward Islands: land-sea interactions in a changing ecosystem. Stellenbosch: SUN Press, 121-164.

RYAN, P.G., JONES, M.G., DYER, B.M., UPFOLD, L. \& CRAWFORD, R.J. 2009. Recent population estimates and trends in numbers of albatrosses and giant petrels breeding at the subAntarctic Prince Edward Islands. African Journal of Marine Science, 31, 409-417.

SCHOOMBIE, S., CraWford, R.J.M., MAKhADO, A.B., DyeR, B.M. \& Ryan, P.G. 2016. Recent population trends of sooty and light-mantled albatrosses breeding on Marion Island. African Journal of Marine Science, 38, 119-127.

ShEARN-Bochsler, V., Green, D.E., ConVerse, K.A., Docherty, D.E., Thiel, T., GeISZ, H.N., Fraser, W.R. \& PATTERSON-FraSER, D.L. 2008. Cutaneous and diphtheritic avian poxvirus infection in a nestling Southern Giant Petrel (Macronectes giganteus) from Antarctica. Polar Biology, 31, 569-573.

Sileo, L., SieverT, P.R. \& SAmUeL, M.D. 1990. Causes of mortality of albatross chicks at Midway Atoll. Journal of Wildlife Diseases, 26, 329-338. 
Schoombie et al. (2017) Avian pox in Marion Island seabirds

StanNARD, L.M., MaRiAS, D., Kow, D. \& DumbelL, K.R. 1998. Evidence for incomplete replication of a penguin poxvirus in cells of mammalian origin. Journal of General Virology, 79, 16371646

TAmura, K., Stecher, G., Peterson, D., FiliPski, A. \& KumaR, S. 2013. MEGA6: Molecular Evolutionary Genetics Analysis version 6.0. Molecular Biology and Evolution, 30, 27252729.

UharT, M., GaLlo, L. \& QuinTANA, F. 2017. Review of diseases (pathogen isolation, direct recovery and antibodies) in albatrosses and large petrels worldwide. Bird Conservation International, 0, 1-28.

VAN RIPER III, C., VAN RIPER, S.G. \& HANSEN, W.R. 2002. Epizootiology and effect of avian pox on Hawaiian forest birds. The Auk, 119, 929-942.

vAN Riper III, C. \& ForRester, D.J. 2007. Avian pox. In ThOMAS, N., HunTER, B. \& ATKINSON, C.T., eds. Infectious diseases of wild birds. Oxford: Blackwell Publishing, 131-176.

VANDERWERF, E.A. \& YounG, L.C. 2016. Juvenile survival, recruitment, population size, and effects of avian pox virus in Laysan Albatross (Phoebastria immutabilis) on Oahu, Hawaii, USA. The Condor, 118, 804-814.

WARNER, R.E. 1968. The role of introduced diseases in the extinction of the endemic Hawaiian avifauna. The Condor, 70, 101-120.

WATKINS, B.P. \& COOPER, J. 1986. Introduction, present status and control of alien species at the Prince Edward Islands, sub-Antarctic. South African Journal of Antarctic Research, 16, 86-94. 
Schoombie et al. (2017) Avian pox in Marion Island seabirds

WeImerskirch, H. 2004. Diseases threaten Southern Ocean albatrosses. Polar Biology, 27, 374-379.

Weimerskirch, H., Cherel, Y., Delord, K., Jaeger, A., Patrick, S.C. \& Riotte-Lambert, L. 2014. Lifetime foraging patterns of the wandering albatross: Life on the move! Journal of Experimental Marine Biology and Ecology, 450, 68-78.

YounG, L.C. \& VANDERWERF, E.A. 2008. Prevalence of avian pox virus and effect on the fledging success of Laysan Albatross. Journal of Field Ornithology, 79, 93-98.

ZYLBERBERG, M., LEE, K.A., KLASING, K.C. \& WIKELSKI, M. 2012. Increasing avian pox prevalence varies by species, and with immune function, in Galápagos finches. Biological Conservation, 153, 72-79. 